\title{
THE USE OF VARIOUS READING STRATEGIES TO GET BETTER UNDERSTANDING AND BE CREATIVE READERS
}

\author{
Nina Suzanne \\ Program Studi Tadris Bahasa Inggris, Jurusan Tarbiyah, STAIN Batusangkar \\ E-mail: Nsuzanne.ns@gmail.com
}

\begin{abstract}
Reading is a proses of involving reader's physics and mental. The purpose of reading is not only to get new information passively but also to comprehend the text actively. In order to get good result in reading, a reader needs to apply various strategies. Kinsella (2000) offers several reading strategies such as PACA, KWL Plus, Outlining, and Concept Building. Those strategies could be well implemented based on reader's purpose to read. The ability to apply these strategies could lead someone to be a creative and innovative reader.
\end{abstract}

Key words: Better Understanding, Creative Readers, Reading strategies

\section{INTRODUCTION}

$\mathrm{R}$ eading is an activity that is done everyday by everyone, consciously or unconsciously. Readers can spend hours a day for reading, while the others just need some minutes. Whatever they do, no matter how long they read, and whatever the purpose, they should enjoy their reading activities. Enjoy the reading time can affect student's understanding toward the reading texts, and then take the readers to the level of creative reading by revealing some ideas by using their own words that can give contribution to their own lives and others as well.

The above concept can work well to students also. Unfortunately, with so many things to do, the English students of STAIN Batusangkar cannot enjoy their reading activities well. In Reading subjects, the problem occurs when the students cannot express any information they got from the reading selection, in writing or spoken form. They tend to copy the sentence and get difficulty to expose the idea by using their own words.

Actually, students should be able to catch any informative and important information from their reading materials actively. It means that beside getting something new, they should think on the quality of the information, and later on can share it to others. Nurhadi (2004:57) explains that in reading for understanding, there are three ability in reading; literal, critical and creative reading. Literal reading means an ability to catch the explicit information. Critical reading means an ability to analyze or evaluate the implicit information. Last, creative reading is an ability to apply or expose the ideas they got creatively.

In line with the above idea, McWhorther (1994: 4) explains that reading is thinking. It is an active process of identifying important ideas and comparing, evaluating, and applying them. It is hoped that students can get good understanding to be creative readers. That's why in reading activities, they need some strategies to help them. 
According to Kinsella (2000:2), learning reading strategies can help readers better understanding anything they read. It is good for readers' long term memory because by using reading strategies, readers should respond what they read with questions, ideas, and opinions.

\section{DEFINITION AND THE IMPORTANCE OF READING STRATEGIES}

Everyone, probably uses one reading strategy when he/she reads a text. When the reading process is started by looking at the text at glance, then pay attention to the picture or table (if available), and read the title, it means that the reader already has a strategy in reading.

In general, strategy can be defined as a guidance to act in order to reach a certain goal (Djamarah and Zain, 2006: 5). In relation to reading, strategy means a kind of guidance that can lead readers to achieve their goal in reading. Kinsella (2000: 2) explains that reading strategies are techniques that can help readers understand better anything they read. Readers as if have a conversation with the author of the text and get involved with what they are reading.

Furthermore, Kinsella (2000: 2) states that different strategies work well for different kinds of reading. Reading strategy that is used to read an advertisement and an article in a scientific journal is different, because the two reading activities have different purpose. A good competent reader knows how to differentiate the relevant information from the irrelevant one, and also knows when to read more deeply one reading selection.

In line with the above concept, Grellet (1981: 3) explains that it is essential to take some elements into consideration in applying reading strategies, they are: 1). What do we read? It can be novels, short stories, newspapers, essays, statistics, etc. 2). Why do we read? The reasons are reading for pleasure and reading for information. 3). How do we read? Readers can apply skimming, scanning, extensive, or intensive reading, etc. When readers know exactly what they will do, they can choose the appropriate reading strategies to fulfill the purpose of their reading activity.

Tarigan (2008: 120) has the same idea with Grellet. He says that to be a good reader, someone should; 1) know what he reads, 2) understand what he reads, 3) improve his reading speed, and 4) familiar with printed media such as paperbacks, newspapers or magazines. The two experts concerns on how important the readers know what, why and how to read.

Next, Duffy (2009: 13) defines strategy as a plan. When someone has a reason to do something, he/she will adjust a plan to realize it. In reading, making predictions is a strategy because readers are thoughtful in using text clues and prior knowledge to make an initial prediction, but they remain ready to change adjust a prediction when subsequent text clues provide more information.

\section{KINDS OF READING STRATEGIES}

Strategies are important parts of comprehension. Usually, a strategy consists of a combination of several skills. As it is explained by Duffy (2009:19), reading strategies can contain the following elements:

$\checkmark$ Making predictions

$\checkmark$ Monitoring and questioning what is happening

$\checkmark$ Adjusting predictions as you go.

$\checkmark$ Creating images in the mind

$\checkmark$ Removing blockages to meaning 
Reflecting on the essence of the significance or the importance of what has been read.

Furthermore, Duffy (2009:19)

divides reading strategies into four, they are:

1. Before you begin reading strategies

The best reading experience should be began by asking themselves, "Why am I reading this?" It means that a reader should set a clear purpose of reading.

2. As you begin reading strategies

Predicting is the strategy relied upon most as you begin. Predictions can be based on three kinds of prior knowledge:

a. Prior knowledge about the purpose of the reading.

b. Prior knowledge about the topic.

c. Prior knowledge about type of text.

3. During reading strategies

The primary strategy used during reading is a combination of monitoring, questioning, and repredicting. This cycle is repeated over and over again as the reader proceeds through text.

4. After reading strategies

Comprehension does not stop when the last page of a selection is read. Good readers reflect after they read. They need to find out whether they have achieved the purpose. The following are important after reading strategies: deciding main idea, determining theme, summarizing, drawing conclusion, evaluating, and synthesizing.

Kinsella (2000:4) divides reading strategies based on different types of reading. The strategies are:

1. PACA (Predicting And Confirming Activity)

In using this strategy, an active reader will be led to make a prediction based on what he reads. This strategy becomes more effective if the reader has prior knowledge about the topic.
To apply this strategy, a reader should prepare a chart like below:

\begin{tabular}{ccc}
\hline Prediction & $\begin{array}{l}\text { Confir } \\
\text { mation }\end{array}$ & Support \\
\hline
\end{tabular}

The steps are as follow:

a. Predict what you might learn in the article.

b. Read, then confirm your predictions

c. Support your predictions with details

\section{Cornell Note-Taking}

This strategy needs a chart that will help readers to write down any main points and supporting information they got from the text. A good note is writing anything you read.

\begin{tabular}{cc}
\hline Main & Evidence/Details \\
Points & \\
\hline
\end{tabular}

The steps are:

a. Preview what you will read

b. Read, then take notes

c. Summarize what you have read

d. Review what you have learned

3. KWL Plus (Know, Want to know, Learned)

A good reader will think about what he will read and what he is reading about. In this strategy plus means writing summary.

The chart used for this strategy can be like the following:

\begin{tabular}{cccc}
\hline Know & $\begin{array}{c}\text { Want } \\
\text { to } \\
\text { know }\end{array}$ & \\
& & \\
\hline
\end{tabular}

The steps are:

a. Write what you know about the topic 
It will help you connect what you know and what you learn.

b. Write what you want to learn Readers can write some questions that will help them focus on their reading and organize their thinking as their read.

c. Write what you learn

Readers can write any important facts or ideas they got and pay special attention to write the ideas that can answer their questions.

d. Write a summary of what you have learned

The summary is written with the information the readers wrote in $\mathrm{K}$, $\mathrm{W}$, and $\mathrm{L}$ column. The summary ensures that the readers remember what they have read.

\section{Concept Building}

When concept building strategy is used, readers learn each term or concept as it is presented. Then, review what they have learned. To apply this strategy, a chart should be prepared as follow.

\begin{tabular}{|l|l|l|l|}
\hline $\begin{array}{l}\text { Co } \\
\text { nce } \\
\text { pt }\end{array}$ & $\begin{array}{l}\text { Definiti } \\
\text { on/form } \\
\text { ula }\end{array}$ & $\begin{array}{l}\text { Evide } \\
\text { nce/st } \\
\text { eps }\end{array}$ & $\begin{array}{l}\text { Review } \\
\text { lexamp } \\
\text { les }\end{array}$ \\
\hline & & & \\
\hline
\end{tabular}

The steps are:

a. Preview to find the main concept In previewing, readers look for specific things to find the concept such as word in boldface or dark type which is often followed by definition or explanation.

b. Explain the concept

c. Write the steps or the evidence for the concept

At this step, readers read the passage. After reading, they write the evidence or details that explain each concept in the evidence or steps column.

d. Review what you have learned
Reviewing is important to make sure that readers understand what they have read.

In another book, Kinsella (2000: 4) explains three more reading strategies. They are as follow:

\section{SQ3R}

SQ3R is short for Survey, Question, Read, Retell, and Review. To apply this strategy, a reader needs a chart like the following:

Survey Question Read Retell

SQ3R consists of several steps, they are:

a. Survey what you will read

Readers looks quickly at the text; the title, subheadings, the first and last sentence of each paragraph, and ask themselves what it is about.

b. Ask questions about what you might read.

Readers can write some questions about anything they want to get from the text.

c. Read the selection

While reading, readers try to look for the answers to their own questions. Then, write the answer in the read box. If they find another important questions, they write it also in the read box.

d. Retell what you have learned

Retell means making summary by putting the information into your own words.

e. Review what you have learned There are some ways readers can do to review; go back to the questions and see whether they can find the answers, discuss with another reader/student, or check memory by making a few notes about the review's main point. 
2. Outlining

Outlining can help readers make sense of what they read by highlighting the text's main points and details that support them. The steps are:

a. Preview what you will read

Readers look at the title, the subheadings, and the topic sentences.

b. Read, then make an outline

The outline can be written in a form that is usually used for reports. Roman-numeral lines show major ideas; capital-letter lines show points that are part of each main idea. Number lines show evidence that supports each point on a capital-letter line, and so on.

c. Summarize what you have read Finally, the outline is used to write a summary of the article.

\section{DRTA}

DRTA stands for Directed Reading and Thinking Activity. This strategy works well when readers can make some predictions about what they will read. To apply this, a chart is needed as follow:

\begin{tabular}{ccc}
\hline Preview & $\begin{array}{c}\text { Take } \\
\text { Notes }\end{array}$ & Review \\
\hline
\end{tabular}

The steps are:

a. Preview the article and predict what you will read

After previewing the text, students write anything they got in preview box.

b. Read, then take notes

As readers read, watch for the evidence that support their predictions. When finished reading, write the evidence for the prediction in the take notes box.

c. Review what you have read
Students can check their understanding by writing a summary of the article. To summarize, students should put the author's thought into their own words.

\section{HOW TO GET BETTER UNDERSTANDING AND BE CREATIVE READERS}

There are many strategies that can be chosen by students to help them get better understanding. They can use different reading strategies for different kinds of text. Because one strategy can work best for one type of reading selection, and another works well for another kind of article.

Basically, all kinds of reading strategies can be applied to read various texts. Students can use the seven strategies to read texts of language art, social studies, science, and also mathematics. However, each reading strategy has its own strengths and weaknesses. KWL Plus can work well if the readers have background knowledge about the topic while Concept building is appropriate for match and science readings.

Dealing with creative readers, applying reading strategies can lead students to improve their ability in reading and be creative. Nurhadi (2004:11) explains that to improve his ability in reading, someone should:

1. Realize that each reading activity has its own purpose.

2. Organize the reading activity well.

3. Develop various reading strategy.

4. Practice reading with various reading purposes.

5. Realize that a good reader is able to use various reading techniques dealing with the reading purposes.

Based on the statement above, it is clear that reading strategies are the way to get good understanding and be 
creative readers. However, to be effective in reading activity, different text with different purpose, needs different and appropriate reading strategy. Creative reading is the highest ability in reading. Beside understanding the literal and implied meaning, a reader should be able to expose his understanding by writing summary in his own words, discussing with friends or other readers about the topic, or even create a new idea or concept based on his understanding.

Harvey and Goudvis (2007: 181) explains that in summarizing, readers remember to tell what is important, tell it in a way that makes sense, and try not to tell too much. The three things can be the guidelines for readers to restate the content of a text in their own words. Readers can record their thinking on a chart or on a sticky note. It is important for the readers to just write the most important information and keep it brief in their summary.

Furthermore, Nurhadi (2004:60) mentions some characteristics of creative readers:

a. Reading activity does not stop at the last page.

b. Be able to apply his understanding for his daily activity.

c. A new and better habit and behavior is set after reading process.

d. Useful forever

e. Evaluate a reading selection critically and creatively.

The application of reading strategies can guide readers to be creative as long as they use the strategy seriously and follow the instruction well. The use of a reading strategy to read a passage can be shown below.

Direction: Read and understand the following passage by using one of the reading strategies.

\section{Flag-raising Ceremony and National Pride}

\section{Donny Syofyan}

Al Irshad Al Islamiyyah Junior High School and Al Bani Primary School, two Islamic schools in Karanganyar, Central Java, have been in the spotlight over the past few days for their refusal to hold the mandatory flag-raising ceremony. Sutardi, the principal of Al Irshad, has insisted that saluting the flag was against his Islamic beliefs. According to him, saluting the flag was akin to shirking one's duties to God.

Not long after this, seven teachers at state schools in the district were also found to have flouted a ministerial decree that requires students to salute the flag and sing the national anthem. Karanganyar district chief Rina Iriani threatened to close down both establishments and dismiss the teachers from the civil service.

The incident adds to a number of recent attacks on Indonesia's struggle to maintain the current poor level of patriotism among the population. A lack of pride at being Indonesian has become and remains rife. Now, an assault on nationalism comes from within instead of from external elements, and is clearly visible in the following issues.

First, our citizens seem to now have less respect for the state symbols, such as the national flag, anthem and state ideology (Pancasila). This behavior stems from multifaceted backgrounds. Seen from the background factor of their schools, they have a close relation to and are influenced by firebrand cleric Ja'far Umar Thalib. This figure is notorious for his radical and intolerant Islamic views. 
A strict interpretation of such Islamic campaigns stipulates that saluting the national flag is not simply a tradition of infidels who exaggerate respect toward their leaders, but also the glorification of an inanimate object. For sure, this interpretation is bolstered by a parochial and textual understanding of Islamic teachings. In the discourse of national insight, reverence for the national flag cannot be equated to the worship of God. This issue should thus be resolved through sustained dialogue.

Poor leadership and politicians also contribute to putting the country's state symbols into a corner. People no longer respect the Pancasila as the state ideology, for example, since they see so-called leaders as only implementing the Pancasila in books, writing and speeches, but then betray it in their daily lives. In a nutshell, while radical religiousness accounts for their tolerance, the living examples set by Indonesia's poor politicians make the community allergic to and lose trust in the state symbols.

Second, historical amnesia has been growing among our citizens. Indonesian heroes' sacrifices were paid in blood in their struggles to raise the red and white flag for the country's independence in 1945. Our heroes and founding fathers viewed the flag as a symbol representing the spirit, hopes and ideals of a nation. The flag is a peaceful sign of these heroes' wish for a united and unitary state of Indonesia. They were patriotic and loved their country, and it is to their struggle we pay our respects when it comes to saluting the flag.
There is also huge possibility that this denial of the importance of state symbols is inseparably linked to a lack of learning about Indonesia's history, which in turn leads people to fail to understand the human story behind Indonesia. Political instability and economic pressure during and after the reform era have raised one generation after another in this country of young Indonesians who are, by and large, historically illiterate.

Hence, the best way to fix this problem is to bring conversations about Indonesian history back to the dinner table, take children and youngsters to historical landmarks and give them books, and require teachers to have an education in history, not just degrees. Historical amnesia is a dangerous phenomenon, not only because it decreases a sense of belonging to the nation, but also lays the groundwork for social tension among our fellow citizens.

Third, the declining intellect of leaders leads to public disorientation. Frankly speaking, people are getting bored of politicians who have turned their backs on moral integrity. Antonio Gramsci names them "politicians without ideology." Such politicians never get involved in social transformation to serve public interests. Indeed, they succeeded in obtaining scholars' degrees from various universities, but they reach their seemingly intellectual status through corruption, public lies and poor accountability.

Our founding fathers were capable of instilling in the Indonesian people a strong sense of nationalism because of their own sincere commitment, honest 
idealism and intellectual integrity. These factors served as their capital, making them figures of reflection and action, which left no yawning gaps between saying and doing.

They were intellectual leaders whose dialectical thinking was oriented toward people's interests rather than glorifying themselves in a self-admiring ways. Their intellectual traces benefit people and last longer. Tan Malaka's political thoughts in Madilog, the thoughts of Mohammad Hatta on democracy and cooperative, or Sutan Sjahrir's grand design of Indonesian socialism, remain relevant and irreplaceable.

In a short, they have left some sort of legacy - commitment, thoughts, action, and of course a nation - with a view to developing and preserving loyalty to this country. Now, it is saddening to learn that their legacy has been transformed into pieces in Indonesia's recent democratic period.

The writer, a graduate of the University of Canberra, is a lecturer at Andalas University, Padang.

(Source: The Jakarta Post)

Let's take KWL Plus as the strategy chosen to understand the text above. For beginners, a lecturer or a teacher can guide their students to use this strategy.

1. First of all, make sure that the readers have background knowledge about the topic because KWL Plus can work well with it. Next, the lecturer informs the title, and ask students to think about it.
2. Ask the students to draw the KWL Plus chart.

\begin{tabular}{|c|c|c|c|}
\hline Know & $\begin{array}{l}\text { Want } \\
\text { to } \\
\text { know }\end{array}$ & Learned & Summary \\
\hline
\end{tabular}

3. The students are asked to think about the topic and write anything they know about it.

\begin{tabular}{l}
\hline Know \\
\hline 1. Flag raising ceremony is held \\
in schools every Monday \\
morning. \\
2. It is a part of nationality \\
3. Some students do not follow \\
the ceremony seriously
\end{tabular}

4. Next, the students are asked to write some questions about anything they want to know from the passage.

\begin{tabular}{l}
\hline What I want to know \\
\hline 1. What is the true meaning \\
of flag-raising ceremony? \\
2. Does follow the ceremony \\
mean good nationality? \\
3. What do people say about \\
it recently?
\end{tabular}

5. Next step, the students read the passage and should focus their mind to find the answer for their questions and also get the important information. What they got after reading is written in $\mathrm{L}$ box.

\section{What I have learned?}

1. Flag raising ceremony is a symbol of nation, respect the nation struggle.

2. Respect and give salutation

3. nationalism is decreased.

4. Some schools in Java denied the ceremony.

5. The government and the people should go back to the 
history.

6. Better nationalism is needed for better nation.

7.

6. Without going back to the passage, the students write the summary just by using the information in the chart.

\begin{tabular}{l}
\hline Summary \\
\hline Flag raising ceremony is a \\
symbol of nationalism. \\
Indonesian people should respect \\
it to strengthen the nation. \\
Unfortunately, lately, some \\
people denied holding this \\
ceremony because of some \\
reason. .........
\end{tabular}

In following the steps and filling in the columns, the students should have self confidence by writing the ideas by using their own words. Because it will help them remember the information for a long period. Avoiding reread the passage is helpful. Later on the students can retell the topic to their friends in a group or in front of the class to the

\section{BIBLIOGRAPHY}

Djamarah, Syaiful Bahri and Aswan Zain. 2006. Strategi Belajar Mengajar. (Edisi Revisi). Jakarta: PT. Rineka Cipta.

Duffy, Gerald G. 2009. Explaining Reading. A Resource for Teaching Concepts, Skills, and Strategies. New York: A Division of Guilford Publications, Inc.

Grellet, Franscoise. 1981. Developing Reading Skills. A Practical Guide to Reading Comprehension Exercises. Cambridge: Cambridge University Press. whole class. Dealing with the characteristics of creative readers, after reading this passage, it is hoped that the students will respect more the flag raising ceremony by practicing it in his life. Beside that, the students can create a discussion forum talking about the topics by adding some facts and opinions, or for those who are interested much in writing can compose an essay about the topic from his point of view.

\section{CONCLUSION}

Reading without understanding is useless. However, understanding is not the only goal that should be reached by the students. Good understanding should give influence to the students' life. Starting the reading process by setting the purpose, reaching the comprehension by applying certain reading strategies, and ending the reading by creating an essay or article and get involved in discussion forum actively. The process that the students follow will lead them to be creative.

Harvey, Stephanie and Anne Goudvis. 2007. Strategies that Work. Maine: Stenhouse Publishers and Ontario: Pembroke Publishers Limited.

Kinsella, Kate. 2000. Reading in the Content Areas. Strategies for Reading Success. Level B. New Jersey: Pearson Education, Inc.

2000. Reading in the Content Areas. Strategies for Reading Success. Level C. New Jersey: Pearson Education, Inc.

McWhorter, Kathleen T. 1994. Academic Reading. New York: HarperCollins College Publishers. 
193 Nina Suzanne, The Use of Various Reading Strategies To Get Better...

Nurhadi. 2004. Bagaimana Meningkatkan Kemampuan Membaca? Suatu Teknik Memahami Literatur yang Efisien. Bandung: Sinar baru Algesindo.
Tarigan, Henry Guntur. 2008. Membaca. Sebagai Suatu Keterampilan Berbahasa. Bandung: Percentakan Angkasa.

The Jakarta Post. 